KOSTA NIKOLIĆ, naučni savetnik

Institut za savremenu istoriju

UDK 323(497.11)"1988/1991"

Beograd, Trg Nikole Pašića 11

316.344.32(497.11)"1988/1991"

\title{
HUMANISTIČKA INTELIGENCIJA I OBNAVLJANJE PARLAMENTARIZMA U SRBIJI*
}

\begin{abstract}
APSTRAKT: $U$ članku se razmatraju društvena atmosfera $i$ dominanti politički procesi u Srbiji u vreme sloma realnog socijalizma, jugoslovenske krize i obnavljanja višestranačkog poretka. U centru analize jesu odnos humanističke inteligencije prema režimu Slobodana Miloševića, vladajuća oligarhija i njena nespremnost da izvrši punu demokratizaciju Srbije, kao i delovanje prvih opozicionih stranaka.
\end{abstract}

Ključne reči: Srbija, Jugoslavija, inteligencija, socijalizam, parlamentarizam, demokratija, diktatura

Višestranački sistem u Srbiji nastao je iz Miloševićeve populističke „antibirokratske revolucije“. Sve značajnije srpske političke stranke svojim programima, još više delovanjem, samo su pratile osnovne smernice koje su postale dominantne u srpskom javnom mnjenju u periodu posle 1988. i delovali su isključivo dnevnopolitički, prateći (više) ili negirajući (manje) ono što je Milošević postavio kao politički standard - jedinstvena Srbija i Jugoslavija kao federacija. Zato i nije stvorena realna alternativa njegovom ideološkom sistemu i zato je on ubedljivo i bez nekog većeg napora pobedio na prvim izborima. I u kasnijem periodu Miloševićevi suparnici kasnili su za njim, bilo da je on vodio ratnu ili mirotvornu politiku. Taj kompleks pratio je srpsku opoziciju punu jednu deceniju.

\section{Milošević i srpska humanistička inteligencija}

I posle pojave na političkoj sceni i događaja oko Osme sednice SK Srbije kritička inteligencija je i dalje bila „oprezna“, Milošević je još uvek smatran za autentičnog titoistu koji je dobio prećutnu saglasnost pokrajinskih rukovodstava u osvajanju vlasti na Osmoj sednici. Ne samo da je predstavljao oličenje sistema kome su se intelektualci suprotstavljali, već je u vreme dok je bio na čelu beo-

${ }^{*}$ Rad je deo projekta Srpsko društvo u jugoslovenskoj državi u 20. veku-Između demokratije i diktature (177016) koji finansira Ministarstvo prosvete i nauke Republike Srbije. 
gradskih komunista, a zatim i cele srpske Partije, i lično organizovao njihov progon. Ali, istorija je nepovratno krenula u drugom smeru. ${ }^{1}$

Milošević neangažovanje u napadima na Memorandum SANU počelo je postepeno da mu se isplaćuje i on je u delu nacionalno orijentisane kritičke inteligencije već tada počeo da stiče popularnost. Prvi korak koji je Milošević učinio kako bi se približio inteligenciji, bila je pažnja koju je posvećivao Univerzitetu. Iako ograničena na dogmatske snage okupljene oko njegove supruge, to je bila velika promena u odnosu na njegove prethodnike. Tako je on 1987. rekao kako se balkanski dogmatizam izražavao u „gotovo feudalnom pogledu“ na inteligenciju. Borba za ekonomski i društveni poredak nije mogla da bude dobijena „ako u prvim redovima borbe nema obrazovanih, sposobnih i pametnih ljudi“".

Mnoge liberalne institucije, nekadašnji opozicioni bastioni, počele su polako da podržavaju Miloševića, što je samo govorilo o posledicama intelektualnog sazrevanja u društvu neslobode. Tako je Odbor za odbranu slobode misli i izražavanja krajem 1987. zahtevao slobodne, višestranačke izbore, a već 12. februara 1988. kao svoj glavni zahtev isticao je ,uspostavljanje stvarne ravnopravnosti naroda Jugoslavije" i osnivanje samoupravnih oblasti za srpski narod, i u Hrvatskoj i u Bosni i Hercegovini. Miloševićeva zahvalnost stigla je veoma brzo. Odbor je u julu 1988. izradio Predlog za slobodno i kritičko preispitivanje istorijske uloge J. B. Tita, što je izazvalo veliko negodovanje federalnog partijskog Predsedništva, Socijalističkog saveza, kao i niza boračkih, omladinskih i drugih organizacija. Ali, srpsko rukovodstvo - navodno glavni branilac Titove zaostavštine ostalo je potpuno uzdržano. Predlog su potpisali Tanasije Mladenović i Mića Popović. Obelodanjen je 29. jula u ljubljanskoj „Mladini“, a u njemu je, između ostalog, stajalo da „politička uloga bivšeg jugoslovenskog predsednika Republike još nije stavljena u objektivan istorijski kontekst", kao i da savremena jugoslovenska istoriografija i pedagoško shvatanje i tumačenje savremene istorije Jugoslavije ,i danas imaju pretežno partijski i ideološko-propagandni karakter“. Konstatovano je i da su društvene nauke još uvek ograničene ,ideološkom mitologijom i partijskim tabuima i izložene neprestanim udarima birokratskog subjektivizma i funkcionerske ideologije. Za slobodno, objektivno procenjivanje uloge Josipa Broza kod nas ne postoje objektivne slobode“.

Preloman trenutak u uspostavljanju ,narodnog jedinstva“ nastupio je leta 1988. kada je u punom zamahu bila „antibirokratska revolucija“ $i$ kada je Slobodan Milošević ustoličen za nacionalnog vođu srpskog naroda. Tako je pokrenut proces homogenizacije naroda kako bi se oblikovao najvažniji politički projekat - ujedinjenje srpskog naroda.

Milošević je početkom jula 1988. u intervjuu objavljenom u NIN-u, za razliku od ranijeg zalaganja za diferencijaciju između ,progresivnih“ i „,nacionalističkih elemenata“, pozivao na slogu svih nacionalnih snaga, koje žele da preovladaju ekonomsku krizu, uspostave Srbiju kao državu i izvedu reformu federacije.

${ }^{1}$ Slobodan Milošević, Godine raspleta, Beograd 1989, 198. 
Delovi intervjua u kojima je izričito rekao da je komunista, u kojima je branio ideju socijalizma, u kojima se pozivao na Lenjina a sve kritike na njegov račun ili račun SK Srbije označio kao „fašističke“, u kojima je rekao da je Jugoslavija održiva samo kao socijalistička zemlje - pripadnici srpske kritičke inteligencije kao da nisu čitali. U njihovu svest urezali su se samo oni delovi intervjua u kojima je Milošević inteligenciju glorifikovao kao „našu veliku, neprocenjivu vrednost“, a napade na nju označio kao „zlonamerne i ružne“.

Za prethodno loše odnose koje je Partija imala sa inteligencijom, okrivio je ,neke nedovoljno obrazovane političare“ $\mathrm{i}$, duhovno i profesionalno inferiorne pojedince“ koji su smenjeni: „, Tu netrpeljivost nekih političara prema inteligenciji hranili su i podsticali upravo pojedinci iz redova inteligencije koji su bili profesionalni i dežurni tumači svake politike, pristalice svake političke garniture. Srećom, pred nama je vreme u kome u politiku ulazi mnogo ljudi koji imaju i opšte i stručno obrazovanje na visokom nivou, koji su i sami deo inteligencije, pa im nisu potrebni 'specijalni intelektualci', da im tumače društvo, pišs referate, nerviraju kulturne ljude i stvaraju zabunu kod naroda “.

Upravo u ovom periodu desilo se nešto što je uverilo srpsku inteligenciju da se „stvari menjaju“. „Književne novine“ su 1. jula (br. 757/758) objavile jedna polemički tekst Zločinci $i$ žrtve Dragoslava Mihailovića u kome je govorio da su Goli otok izmislili Tito, Kardelj, Ranković i Đilas. Beogradski javni tužilac zabranio je dalju distribuciju „Novina“ zbog ,neistinitih i zlonamernih tvrđenja o ogromnom broju žrtava na Golom otoku i odgovornosti najviših partijskih i državnih rukovodilaca čime se može uznemiriti javnost". Ali, Okružni sud u Beogradu je 11. jula, posle Miloševićevog intervjua NIN-u, odbacio ovaj predlog. ${ }^{3}$

Dejan Medaković je pisao kako je bilo „očigledno“ da Slobodan Milošević ima zasluge za to: „Ovaj njegov potez biće ocenjen negativno od svih onih kojima on ne odgovara. Jer, po njega je najgore što nije slabić i političar kova Petra Stambolića i Draže Markovića, Miloša Minića i Dušana Vasiljevića, što će protiv sebe udružiti političare iz drugih republika sa srpskom partijskom opozicijom kojoj smeta". ${ }^{4}$

Miloševića i većinski deo srpske humanističke inteligencije spojila je njegova konzervativna, tzv. antibirokratska revolucija. On je pokrenuo borbu za jačanje starog modela socijalizma (centralistički) sa znatno povećanom ulogom države u njemu; inteligencija je u tome prepoznala borbu za jaku srpsku državu u kojoj će konačno biti rešeno srpsko nacionalno pitanje. Miloševićeva revolucija bila je konzervativna revolucija. Ona je uključivala i silu i (revolucionarno) nasilje, ako je i kad je ono opravdano kako bi se postigli revolucionarni ciljevi.

Dok se u većini drugih zemalja nekadašnjeg socijalizma dogodila revolucija koja je gledala napred, u građenje nekog novog, dotad neviđenog društvenog

\footnotetext{
${ }^{2} 47$ pitanja Slobodanu Miloševiću, NIN, 3. jul 1988, 11.

${ }^{3}$ Politika, 12. jul 1988.

${ }^{4}$ Dejan Medaković, Dani, sećanja, V, 1987-1994, Novi Sad, 2008, 129.
} 
projekta, u Srbiji se ona dogodila kao ,povratak na staro“, na revoluciju koja je započeta ali nije dovršena. Za razliku od drugih revolucija u Istočnoj Evropi, u ovoj je komunistički aparat, predvođen Miloševićem, imao glavnu organizacionu i dominantnu ideološku ulogu. Revolucija se u Srbiji dogodila iznutra, iz samog komunističkog okruženja, uz potiskivanje alternativa. Zato je ona bila konzervativna jer je, pod snažnim egalitarističkim nasleđem o „društvu pravde“, vratila logiku revolucije, sa svim nasiljem koje revolucije uvek nose u sebi, i jer je odložila pojavu one druge, liberalno-demokratske revolucije. Zato se može prihvatiti zaključak D. Jovića da je ona zbog toga suštinski odredila smer srpske politike u sledeće dve decenije, a možda i za duže. ${ }^{5}$

Milošević je tokom leta 1988. ovenčan ,slavom velikana srpske istorije“. Osim partijskog aparata, veliki udeo u tome imala je inteligencija koje je umesto borbe za liberalno društvo podigla barjak nacionalne borbe. Poslednji u nizu velikih mitinga održan je 19. novembra 1988. na Ušću i on je predstavljao državno ustoličenje Slobodana Miloševića. Dominantan Miloševićev diskurs bio je da ujedinjenje Srbije ,više ne može zaustaviti nikakva sila“ i da će bitka za Kosovo biti dobijena bez obzira ne sve prepreke. Milošević je uputio i snažnu kritiku svima u Jugoslaviji koji nisu bili solidarni sa Srbijom u rešavanju kosovskog pitanja. ${ }^{6}$ Istorijski sadržaj ovom mitingu dao je književnik Milovan Vitezović: „Poštovani narode, naša istorija će ovu godinu zapamtiti kao godinu u kojoj nam se dogodio narod “. ${ }^{7}$ Dominantno mišljenje u Srbiji bilo je da je Milošević ispravio sve ,istorijske nepravde“ nanesene srpskom narodu još od stvaranja Jugoslavije, kada je njegovo dostojanstvo bilo „pogaženo“. Osim toga, pošto je Srbija bila politički i ekonomski dominantna, kako se verovalo, sasvim je opravdano bilo i Miloševićevo nastojanje da ona ima vodeću poziciju u državi, odnosno da više ne bude ,vazal“. Najvišu političku tačku tokom 1989. Milošević je postigao na pitanju Kosova i od tada je prihvaćen od ogromne većine srpskih intelektualaca.

Veliko je pitanje da li je srpska kritička inteligencija mogla da se oslobodi stega vremena u kome je delovala. Kriterijum poslušnosti, koji je bio dominantan u partijskoj državi, upravo je najviše došao do izražaja u odnosima između SKJ i inteligencije. Ta inteligencija se trudila jedino da svaki partijski korak, svaku partijsku meru, svaki element partijske politike opravda sa tzv. naučno-stručne strane kako bi SKJ dobio adekvatnu ,,argumentaciju“ sa svoju politiku. U ovom periodu izgledalo je da je nekadašnja kritička inteligencija počela isto da se ponaša kada je u Miloševiću prepoznala (pronašla) političara koga je mogla jednostavno da zameni kao objekat moći. Razlika je u tome što je ovoga puta mogla da izbegne optužbe o poslušnosti, jer je Milošević bio „nacionalni vođa“. Taj model dobro se i veoma jednostavno uklopio u narativ o „narodnoj inteligenciji“ i ,na-

\footnotetext{
${ }^{5}$ D. Jović, Osma sjednica, 61.

${ }^{6}$ S. Milošević, Godine raspleta, 275.

${ }^{7}$ Politika, 20. novembar 1988, 5.
} 
rodnoj“ (narodnjačkoj) državi, što predstavlja suštinu identiteta značajnog dela srpske inteligencije još od druge polovine 19. veka. Srž tog shvatanja kaže da uloga inteligencije nije u tome da bude korektiv epske istorijske svesti, već da „biranim“ i ,učenim“ rečima opravda njen smisao.

Milošević je i u ovom segmentu osvajanja vlasti uspeo da izvrši preokret. Početni mehanizam bio je dosta jednostavan - stranice državnih štampanih medija iznenada su otvorene za opozicionu intelektualnu elitu Srbije. Oni ljudi koji decenijama nisu smeli ni da se spomenu u vladinim listovima ili TV programima, odjednom su dobili priliku da govore i pišu o stanju u Srbiji. Jedino ograničenje bio je izbor tema - on je sveden na „nepravedan“ i „ponižavajući“ položaj Srbije i srpskog naroda u tadašnjem poretku. ${ }^{8}$

Od tada je Milošević dopustio liberalizaciju srpske kulturne scene, što je mnoge opozicionare, pa čak i najnepokolebljivije antikomuniste, navelo da pozdrave ,antibirokratsku revoluciju“ kao početak demokratizacije Srbije. Bivši disidenti došli su u situaciju da ih mediji saleću, kao i da objavljuju dugo zabranjivane radove. Dobar deo pripadnika srpske liberalne opozicije pristao je na Miloševićevo ograničenje i započeo je saradnju sa njim. Jedni iz „,nepromišljene dragosti“ što su najzad dobili priliku da nešto javno kažu, a drugi zbog pogrešne procene da je Milošević na taj način krenuo putem demokratije. Najzad, bilo je i dosta onih koji su sarađivali iz ,puke koristi“ koja prati svaku saradnju sa nosiocima vlasti. ${ }^{9}$

Iz redova disidenata Miloševićevo poverenje prvi su stekli književnici Miodrag Bulatović, Brana Crnčević i Antonije Isaković, koji je izjavio: „,Mislim da je Milošević nekim svojim potezima i nastupima pokazao iskustvo koje je krasilo Karađorđa, ali i iskustvo koje je krasilo visprenog knjaza Miloša “. ${ }^{10}$ Ubrzo su im se pridružili i drugi intelektualci. Kako piše Slavoljub Đukić, novi lider im je uzvratio „lepom pažnjom“ i predusretljivošću: „Baš mi je drago što vas Vidim, toliko smo se svi za Vas brinuli“ - rekao je na jednom prijemu slikaru Mići Popoviću koji se upravo vratio iz Londona posle preležanog infarkta. ${ }^{11}$

Tada su intelektualci disidenti ublažili svoje suprotstavljanje režimu i prihvatili komunističkog predsednika Srbije kao lidera nacije. Zašto je to tako, nije jednostavno odgovoriti. Razlozi koji su vidljivi tiču se nacionalne politike, jer je kod tih intelektualaca nacionalno prevladalo demokratsko. Pošto je novi srpski „,vožd“ branio kosovske Srbe i izvršio čistu nepopularnih birokrata koji su u kolektivnoj svesti nosili odgovornost za podelu Srbije, to im je govorilo o ,kvalitativnoj promeni“" u nacionalnoj politici režima. Prevladalo je naivno političko uverenje da se demokratija može odložiti dok se ne reši nacionalno pitanje. ${ }^{12}$

\footnotetext{
${ }^{8}$ S. Antonić, Zarobljena zemlja, 93.

${ }^{9}$ Isto, 94.

${ }^{10}$ Navedeno prema: Slavoljub Đukić, Lovljenje vetra. Politička ispovest Dobrice Ćosića, Beograd 2001, 156.

${ }^{11}$ Isto.

${ }^{12}$ Jasna Dragović Soso, ,Spasioci nacije“. Intelektualna opozicija Srbije i oživljavanje nacionalizma, Beograd 2004, 301.
} 
To je više nego jasno ukazivalo da Srbija nije bila sposobna da izvede demokratsku transformaciju i odbaci svoje totalitarno nasleđe, jer je ono postalo značajan deo kolektivnog političkog identiteta. Sudbonosna odluka intelektualne opozicije da naciji da prednost nad demokratijom i zastoj u njenoj aktivnosti koji je zbog toga usledio, dali su Miloševiću mogućnost da učvrsti svoju vlast u Srbiji. Kad su nekadašnji disidenti shvatili da su napravili grešku i vratili se svojoj borbi za sistemske promene, bilo je suviše kasno. ${ }^{13}$

Miloševićeva paralelna odbrana Srbije i Jugoslavije takođe je bila u skladu sa zalaganjima inteligencije. Kako je on sam rekao novembra 1988: „Titova Jugoslavija je stvorena u slavnoj revoluciji i neće izdahnuti za konferencijskim stolom “. Pošto je već odavno video sebe kao Titovog naslednika, pozvao je „narod“ da udruži snage za odbranu zemlje. Miloševićeva konzervativna revolucija naišla je na plodno tle, jer je omogućila „narodnjačkoj“ inteligenciji koja se pretežno vodila idejama egalitarizma da se „ponovo pridruži narodu“ u teškim iskušenjima. Osim toga, Miloševićeva ogromna popularnost značila je da će se intelektualci, ako nastave da kritikuju režim, suprotstaviti „narodnoj volji“ i izgubiti svu podršku koju su do tada stekli kao „branioci nacije“.

Niko nije mogao ni da pretpostavi koliko je nekadašnja opozicija komunističkom režimu, književnici pre svega, u sebi nosila pritajen plamen nacionalne borbe, zasnovan na idejama 19. veka o jedinstvu naroda i države u borbi za slobodu. Milošević je bio prihvaćen od naroda - to je bila osnovna ocena kojom su se rukovodili srpski intelektualci kada su promišljali o Miloševićevoj politici. To je jasno ukazivalo da prava intelektualna elita u Srbiji nije postojala. Iako je kult ličnosti, razvijan od moćne partijske mašinerije i uz uključivanje elektronskih medija kao nikada do tada, dostigao zavidan nivo Milošević je uspeo u nečemu što, kako primećuje S. Đukić, do tada nije pošlo za rukom nijednom srpskom političaru - da dobije široku podršku inteligencije: „Teško je bilo prepoznati izvesne učene glave, koje su ranije smelo ulazile u sukob sa Titovim režimom, sa kakvom su toplinom prilazili srpskom lideru. Oni su dali legitimitet njegovoj politici i uveličali njegov ugled u narodu. Oni su ga na otvorena vata uveli u istoriju, sa ljubavlju kojom se nije mogao prepoznati cvet srpske inteligencije ". ${ }^{14}$

Vrhunac Miloševićeve revolucije usledio je 1989. godine - izvedene su ustavne promene (proglašene 27. marta) koje su slomile moć srpskih pokrajina uspostavljenu 1974. Na redu je bila nova bitka, ona za Jugoslaviju. Milošević je

${ }^{13}$ Isto, 302.

${ }^{14} \mathrm{~S}$. Đukić, Između slave i anateme, 126-127. - Odmah na početku nove 1989. srpski režim povukao je jedan demagoški potez - pomirenje sa SANU. Rukovodstvo „Politike“ pozvalo je 6. januara Izvršni odbor SANU da poseti ovu medijsku kuću povodom njenog predstojećeg jubileja - 85 godina od osnivanja. Živorad Minović je održao dug govor u kome je poseban naglasak stavio na kampanju koja je vođena protiv Akademije povodom Memoranduma, ocenivši je politički štetnom i promašenom: „Izrekao je i neku vrstu molbe da Akademija 'oprosti' Politici što je i ova kuća bila uvučena u tu kampanju koja je bila potpuno pogrešna, a pada na teret ranijeg političkog rukovodstva Srbije“. (D. Medaković, Dani, sećanja, V, 217). 
tada otklonio i sve rezerve prema religiji kako bi ojačao svoju nacionalnu orijentaciju i kako bi zamenio dotadašnje jugoslovenstvo i model ,bogatijeg socijalizma“. Tada je on posegao za najsnažnijim elementom nacionalne tradicije - Kosovskim mitom, njegovim etosom i sa njim povezanim skupom emocijama nabijenih simbola. ${ }^{15}$ Kada je Milošević rekao da je spreman i na rat kako bi svi Srbi živeli u jednoj državi, više nije bilo nikakve dileme oko njegovog statusa. Rat je simbolično najavljen na proslavi šest vekova Kosovske bitke (28. juna 1989) na Gazimestanu, kada je Milošević i zvanično „krunisan“ za vođu svih Srba. Iako Milošević nije direktno učestvovao u organizaciji ovog kompleksnog rituala, on je i iz toga uspeo da izvuče jasnu političku korist - država nije napadala ove aktivnosti, što je samo godinu dana ranije bilo gotovo nezamislivo, a državna propaganda dala je veliki prostor procesiji, što je bila nedvosmislena politička poruka. ${ }^{16}$ Naredni simbolički događaj bilo je postavljanje ogromne kupole (tokom maja 1989) na monumentalni Hram Svetog Save u Beogradu i još više, izvođenje prve svete liturgije pod tom kupolom 25. juna 1989. Prisustvo brojnih visokih partijskih i državnih funkcionera i izuzetna medijska pokrivenost događaja potvrdili su njegov veliki politički značaj - trebalo je da pokaže kako je uspostavljeno novo jedinstvo između Crkve, vlasti i naroda. ${ }^{17}$

I onim srpskim intelektualcima koji su se do tada kolebali, izgledalo je da počinje „nova era“ u srpskoj istoriji. Prema službenim podacima, na Gazimestanu je bilo dva miliona ljudi (,nikad ni više ljudi, ni veličanstvenijeg skupa u Jugoslaviji“‘), ${ }^{18}$ a prema neutralnim izvorima do 600.000 građana. Pored puteva koji su vodili na Gazimestan postavljeni su stolovi, a pored njih su bile devojke u narodnim nošnjama. Kneževu trpezu osmislio je slikar Milić od Mačve. U Gračanici je održana sveta arhijerejska liturgija koju je služio patrijarh German; mošti kneza Lazara koje su do tada putovale svim „srpskim zemljama“ iz Gračanice su prenesene u Crkvu Svetog Nikole u Prištini, gde su posle deset dana krenule ka kneževoj zadužbini, manastiru Ravanici. Milošević je još jednom naglasio da je socijalizam „progresivno i pravedno demokratsko društvo“. Zatim je snažno uzviknuo: „Šest vekova kasnije, danas, opet smo u bitkama, i pred bitkama. One nisu oružane, mada i takve još nisu isključene ". ${ }^{19}$

Organizacijom spektakularne komemoracije na polju na kome se „srpska duša uzdigla na nebo“ i u pokrajini koja je predstavljala ključni traumatičan simbol srpskog pitanja u posleratnoj Jugoslaviji, Milošević je demonstrirao da je srpska država ponovo ujedinjena, a da je on njen neprikosnoveni gospodar. Taj ritual doživljen je kao „vraćanje dostojanstva“ celom narodu, a Milošević je svakako bio svestan pozitivnog političkog potencijala transfera emocija sa centralnih

${ }^{15}$ Slobodan Naumović, Upotreba tradicije u političkom i javnom životu Srbije na kraju 20. i početkom 21. veka, Beograd 2009, 66.

${ }^{16}$ Isto, 66-67.

${ }^{17}$ Isto, 67.

${ }^{18}$ Politika, 29. jun 1989, 1.

${ }^{19}$ Navedeno prema: Slobodan Milošević, Prilog istoriji 20. veka, Beograd 2008, 26. 
simbola na one osobe koje se sa njima povezuju, odnosno kojima se manipuliše. Tako je Milošević u epohi rušenja komunizma zaštitio sopstvenu poziciju ,podizanjem jednog novog eteričnog zida od tradicionalnih simbola i nacionalnih mitova". 20

Mnogi mislioci ističi da mit čini osnovu ljudskog društva, jer su mitovi uopšteni iskazi o nacijama i drugim ,intimnom ljudskim grupama“ koji se smatraju istinitim i koji služe kao zamena za instinkt. Trajan Stojanović piše da do sukoba između naroda ne dolazi zato što oni imaju različite mitove već zato što jedan narod omalovažava, prezire i potcenjuje mit drugog naroda. On smatra da su se sukobi u Jugoslaviji zaoštrili kada su Slovenija i Hrvatska omalovažile Kosovski mit Srba. ${ }^{21}$

U svakom slučaju, proslava na Gazimestanu imala je preloman simbolički značaj u podršci intelektualca koju je Milošević od tada imao. Osim toga, većini nekadašnjih disidenata bilo je i nezamislivo i neprihvatljivo da se ponovo vrate u marginalan položaj ljudi beznačajnih za javnost. Dominantan narativ bio je da inteligencija nije napustila svoje ideje već da se režim svrstao uz nju, što je bio ideal kome je težila takva inteligencija. Mnogi su poput Borislava Mihajlović Mihiza smatrali da se inteligencija nije „umilila režimu“ već da se „režim svrstao uz nas“, pa je teško opravdati dalji ostanak u opoziciji. ${ }^{22}$

Udvaranje intelektualcima se isplatilo. Dobrica Ćosić, koji je prvi put posle 1968. dobio pristup medijima, hvalio je Miloševića jer je intelektualcima dao „slobodu koju do tad nisu imali“, dok su dugogodišnji kritičari vlasti, Matija Bećković i slikar Mića Popović, ${ }^{23}$ primali najviše nagrade od režima, pa čak i Miloševića lično, na svečanostima koje su dobijale veliki publicitet. Posebno gorak utisak ostavio je Bećković, nekadašnji antikomunistički simbol i često anatemisan pisac zbog svoje porodične prošlosti, kada je 1989. iz Miloševićevih ruku primio najznačajnije srpsko revolucionarno priznanje - Sedmojulsku nagradu.

Objašnjavajući svoju podršku Miloševićevom režimu, Bećković je rekao kako ne bi razumeo značaj ustavnih promena u Srbiji „da im nije pružen tako kolosalan otpor", jer se dubina promena može izmeriti samo silom koja im se suprotstavlja. Naglasio je i da je borba za Kosovo nastala iz slobode stvaralačkog čina, a sloboda, sama po sebi, mora da bude apsolutna: „Niko nije zakasnio na boj na Kosovu - i još sam može da izabere i ulogu i stranu. Kosovo je svetilište srpske kulture. I ne samo srpske. Kosovo je Krstovo. Kosovo je praznik poezije i pesničkog umeća. Ko god vidi Kosovo - jasno mu je da nije tu slučajno centar srpske države i civilizacije. Ono to treba da bude i danas " ${ }^{24}$

${ }^{20}$ S. Naumović, Upotreba tradicije, 70.

${ }^{21}$ Trajan Stojanović, Balkanski svetovi. Prva i poslednja Evropa, Beograd 1997, 358-359.

${ }^{22}$ Navedeno prema: J. Dragović-Soso, ,, Spasioci nacije“, 308.

${ }^{23}$ Govoreći o aktuelnoj situaciji u Jugoslaviji, Popović je izjavio: „Bratstvo i jedinstvo promovisali [su] srbofobi sa krajnje levice, ne samo da bi zaštitili srbofobe sa krajnje desnice, amortizujući njihovu zločinačku radnju“. (Književne novine, 15. januar 1989).

${ }^{24}$ Najskuplja srpska reč, NIN, 9. jul 1989, 40-41. 
Kad je Milovanu Đilasu, prvom i najprogonjenijem jugoslovenskom disidentu, konačno dozvoljeno da izađe iz izolacije, čak je i on, iskusan i principijelan kritičar komunizma, priznao: „Imam slabu tačku u odnosu na njega. Ja sam kod Miloševića dobio mogućnost da objavljujem svoje knjige. Da li je to bilo sa njegovim znanjem ili nije, ne znam. Ali sam siguran, da je podigao telefon, mogao je štampanje odgoditi barem za jedno dve godine ". ${ }^{25}$

Đilas je kroz doživljaj ličnog tumačio i promene u Srbiji nastale posle sloma komunizma u Istočnoj Evropi: „Što se Jugoslavije tiče, obe ove knjige [Nova klasa i Razgovori sa Staljinom] biće objavljene početkom 1990. u Srbiji. Mogu putovati u inostranstvo, mogu da radim i živim bez političke prismotre ili pritiska. Vetrovi promena dopiru i do Beograda ". ${ }^{26}$

Jedan od retkih intelektualaca koji je u ovom periodu kritikovao Slobodana Miloševića bio je pesnik Ljubomir Simović, koji je 1989. dobio Oktobarsku nagradu grada Beograda za književnost za dramu Boj na Kosovu. On je govorio da je „sudbina države i naroda“ važnija od sudbine sistema: „U onim donedavnim vremenima socijalističkog feudalizma, u kojima su minimalci u radnom vremenu proganjali intelektualce, a u časovima odmora odstreljivali kapitalce, sistem je bio važniji od svega. Zato što su oni bili sistem. Srbija se tog sistema oslobodila u priličnoj meri. A oslobodiće ga se sasvim ako svoju budućnost zasnuje na svojim velikim, višepartijskim, demokratskim tradicijama. Ako ostane bez tih tradicija, ostaće bez budućnosti " ${ }^{27}$

Dominantno mišljenje u Srbiji bilo je da je Milošević ispravio sve ,istorijske nepravde" nanesene srpskom narodu još od stvaranja Jugoslavije, kada je njegovo dostojanstvo bilo „pogaženo“. Osim toga, pošto je Srbija bila politički i ekonomski dominantna, kako se verovalo, sasvim je opravdano bilo i Miloševićevo nastojanje da ona ima vodeću poziciju u državi, odnosno da više ne bude „vazal“. Pojedini intelektualci, od ranije nastanjeni u inostranstvu, bili su „užasnuti““ negativnim stavom Zapada prema srpskom režimu, pa je Milovan Danojlić, jedan od najpoznatijih boraca za slobodu izražavanja u prethodnom periodu, u pismu upućenom pariskom Liberasionu konstatovao kako je prava ironija da zapadni mediji govore o „fašizaciji Srbije“ u vreme liberalizacije kakvu ova republika nije videla još od rata. ${ }^{28}$

Danojlić je nešto kasnije, posle donošenja amandmana na srpski ustav, Miloševiću poslao otvoreno pismo u kome je izjavio: „Ono što si u poslednje dve godine postigao za svoj narod zaslužuje divljenje. Dunuo si život srpskoj duši. Jeste, ništa ne bi postigao bez naroda, ali ni narod bez tebe ne bi mogao izvesti ono što je izveo. Preuzeo si veliki rizik, uzdrmao si žabokrečinu, izveo si prevrat širokih zamaha, isplivao si na čistinu bez činjenja zla. Narod je uz Tebe ostao čist, a

\footnotetext{
${ }^{25}$ Navedeno prema: S. Đukić, Između slave i anateme, 128.

${ }^{26}$ NIN, 22. oktobar $1989,5$.

${ }^{27}$ Politika, 4. novembar 1989, 13.

${ }^{28}$ Navedeno prema: J. Dragović-Soso, ,, Spasioci nacije“, 307.
} 
Ti sa njim uspravan i ispravan. Srpski narod je u Tebi prepoznao svoj ponos $i$ svoj prkos " 29

\section{Stvaranje prvih opozicionih stranaka}

Prva opoziciona stranka u Srbiji - Demokratska stranka - formirana je (obnovljena) 11. decembra 1989. Njeni osnivači obznanili su toga dana Pismo o namerama Demokratske stranke. ${ }^{30}$ Osnivačka skupština stranke održana je 3. februara 1990. i okupila je krem srpske intelektualne opozicije, nekadašnje disidente i ljude nezavisnog mišljenja. Ali, oni su bili heterogeni po svom opredeljenju, što je sprečilo da ova stranka postane jasna alternativa Miloševićevom režimu. Tako su na osnivačkoj skupštini bili i ljudi koji su prethodno dali legitimitet samom Miloševiću (Matija Bećković i Dobrica Ćosić), kao i nekadašnji blizak Titov saradnik a kasnije prvi jugoslovenski disident Milovan Đilas. ${ }^{31}$

Osnovne smernice programa Demokratske stranke bile su: ukidanje monopola vlasti jedne političke stranke, kao i svakog oblika partijske države; uvođenje potpune slobode udruživanja u političke stranke, udruženja i saveze, ,po sistemu prijave bez ikakvog prethodnog odobrenja ili provere, i bez ikakvog uslovljavanja ideološkim razlozima ili organizacionim uslovima“; odbrana ljudskih i građanskih prava, uspostavljanje pune parlamentarne demokratije i tržišne privrede. ${ }^{32}$

Demokratska stranka se založila i za demokratski federalizam, zasnovan na novom ,istorijskom sporazumu“ jugoslovenskih naroda: „Postojeće federativno uređenje Jugoslavije valja dovesti u sklad s osnovnim načelima demokratije tako što će se uz ravnopravnost federalnih jedinica zajemčiti i ravnopravnost građana kao pojedinaca. To se, kao i u drugim demokratskim federacijama, može postići uvođenjem dvodomne strukture saveznog parlamenta u čijem bi jednom domu bile jednako predstavljene sve federalne jedinice bez obzira na veličinu, dok bi u drugom domu građani bili birani u brojčano približno jednakim izbornim okruzima u skladu s klasičnim načelima - jedan čovek jedan glas. Samo na ovaj način dužno uvažavanje dobijaju kao prava građana kako pojedinaca, tako $i$ prava većine, odnosno manjine "33

Demokratska stranka je u svojim programskim načelima iz 1990. bila protiv konfederalnog koncepta preuređenja Jugoslavije koji je predlagan iz Lju-

${ }^{29}$ Književne novine, 15. decembar 1989 - 1. januar 1990.

30 Istorija Demokratske stranke 1989-2009. Dokumenti, priredili: Kosta Nikolić, Bojan B. Dimitrijević, Srđan Cvetković i Slobodan Gavrilović, Beograd 2009, 26-28. - Pismo o namerama potpisali su: Dušan Vukajlović, Vladimir Gligorov, Milovan Danojlić, Zoran Đinđić, Gojko Đogo, Slobodan Inić, Marko Janković, Vojislav Koštunica, Dragoljub Mićunović, Borislav Pekić, Miodrag Perišić, Radoslav Stojanović i Kosta Čavoški.

${ }^{31} \mathrm{Na}$ skupštini stranke, za prvog predsednika izabran je Dragoljub Mićunović, za potpredsednika Vojislav Koštunica, a za predsednika Izvršnog odbora Zoran Đinđić.

${ }^{32}$ Istorija Demokratske stranke, 33-34.

${ }^{33}$ Isto, 41. 
bljane i Zagreba i gotovo da je u potpunosti sledila vladajući koncept Slobodana Miloševića. U dokumentu Nacionalno pitanje $i$ državno uređenje istaknuta su tri osnovna razloga za takvo opredeljenje: 1) konfederacija je bila istorijski preživeo i nedemokratski oblik složene države ,koji, kao takav, potpuno zanemaruje slobodu građanina zarad nacionalne suverenosti“; 2) konfederacija je savez nezavisnih država, ,pa bi za njeno uspostavljanje trebalo prethodno razbiti Jugoslaviju i na njenim razvalinama uspostaviti nezavisne nacionalne države, a kako ne postoji saglasnost o teritorijama koje treba da pripadnu tim novim nezavisnim državama, ovaj pokušaj razbijanja postojeće zajedničke države mogao bi dovesti do građanskog rata ili nove totalitarne diktature“; 3) konfederalizovanje Jugoslavije dovelo bi u pitanje ne samo postojeće državno uređenje već i unutrašnje granice jer ,ove granice nisu utvrđene prema jedinstvenom merilu, već prema različitim merilima za različite federalne jedinice. Ove unutrašnje granice povlačio je od 1943. do 1945. Politbiro CK KPJ na čelu sa Josipom Brozom pod pretpostavkom da će Jugoslavija biti jedinstvena federacija tako da će svaki jugoslovenski narod, čak $i$ ako živi u više federalnih jedinica, biti pod jednim državnim krovom. Ako se ova pretpostavka obara, onda se dovode u pitanje i unutrašnje granice. Demokratska stranka smatra legitimnom težnju svakog naroda da što više svojih sunarodnika okupi pod jednim državnim krovom. [...] Jedna od kobnih opasnosti sa kojima je naša zajednička država suočena jeste mogućnost otcepljenja pojedinih jugoslovenskih naroda. Takva njihova težnja se pod određenim uslovima ne može osporiti, ali im treba staviti do znanja da prilikom izlaska iz Jugoslavije i konstituisanja svoje nezavisne nacionalne države ne mogu polagati pravo na teritorije koje su pretežno naseljene pripadnicima drugog jugoslovenskog naroda. A nacionalna politika srpske države, baš kao i drugih nacionalnih država, mora biti usmerena na to da sve teritorije pretežno naseljene Srbima uđu u sastav jedne države". 34

Usledilo je ubrzano formiranje novih stranaka, uglavnom sa nacionalnim predznakom. U mnogo čemu one su bile radikalnije od Miloševića i dovodile su u pitanje monopol na korišćenje ,narodnosnog obrasca“ opravdavanja vlasti. ${ }^{35}$

Najopasniji suparnik vlasti bio je Srpski pokret obnove Vuka Draškovića. On je otvorio i ona nacionalna pitanja koja čak ni Milošević nije pokretao pitanja granica u slučaju raspada Jugoslavije i stvaranje posebnih jedinica srpske vojske. Nikao je i niz drugih stranaka, ali je zahvaljujući harizmatičnoj ličnosti Vuka Draškovića („kralj srpskih trgova“) SPO privukao najviše pristalica. Stranka se jasno profilisala kao monarhistička i antikomunistička; borila se za rehabilitaciju Ravnogorskog pokreta i generala Dragoljuba Mihailovića („četnika“); zalagala se za obnovu parlamentarne monarhije na čelu sa dinastijom Karađorđević; prihvatala je nezavisnost Slovenije i Hrvatske, ali pod uslovom „otplate“ njihovih ,istorijskih dugova“ Jugoslaviji (jasno je i oštro osuđivan genocid nad srpskim

\footnotetext{
${ }^{34}$ Isto, 55-56.

${ }^{35}$ S. Antonić, Zarobljena zemlja, 97.
} 
narodom u NDH) i promene republičkih granica. Vuk Drašković je često umeo da kaže kako se neće dozvoliti ni secesija ni konfederalizacija „nijednog pedlja zemlje natopljene srpskom krvlju i obeležene srpskim crkvama i grobovima“. Nova srpska država trebalo je da obuhvati sve teritorije koje su do 1918. bile deo teritorije Kraljevine Srbije, ali i one u kojima su Srbi bili u većini pre 1941. i početka ustaškog genocida.

Drašković je bio žestoki antikomunista, njegovi zanosni mitinzi i vatreni govori isijavali su buntovan naboj, samo njegovo prisustvo bilo je dovoljno da ispuni Trg Republike u Beogradu. Druge opozicione partije nisu ga podnosile, ali su koristile njegovu popularnost. Smetala im je Draškovićeva slava i zbrka koju je unosio na političku scenu. ${ }^{36}$ Ostao je upamćen govor Vuka Draškovića u Novom Pazaru. Tamo su ga, osim pristalica, dočekali i ekstremni muslimanski nacionalisti koji su skandirali: „Pobićemo četnike“. Drašković je odgovorio: „, Preseći ćemo čvor poput Aleksandra Makedonskog da bismo mogli dalje i očistićemo čir koji već dugo muči utrobu Srbije. Kad Srpski pokret obnove dobije vlast, Srbijom će lepršati samo jedna zastava - srpska, a svaki onaj ko u ruku ovom Raškom zemljom stegne turski barjak, ustaški barjak, albanski barjak ili bilo čiji drugi državni barjak sem srpskog - ostaće i bez ruke i bez barjaka". 37

Vuk Drašković je 7. septembra 1990. uputio jedno pismo („U odbranu srpstva“) na adrese vodećih političkih stranaka i najznačajnijih srpskih institucija (SANU, SPC, Udruženje književnika Srbije, Matica srpska i Matica iseljenika Srbije) sa predlogom da se sastanu i usvoje zajedničku Deklaraciju o zaštiti nacije. U pismu je, između ostalog, rekao i sledeće: ,U Hrvatskoj je uspostavljena ustaška vlast, osnivaju se oružane formacije Srboubica. Ustaško Vrhovništvo je sklopilo antisrpski pakt sa Arnautima i muslimanskim fundamentalistima, rasrbljenom ali militantnom i glasnom manjinom u Crnoj Gori, kao i srbofobskim štabovima po Makedoniji koji otvoreno traže naše teritorije. Srpski narod je suočen sa ujedinjenom mržnjom kao i 1914. i 1941. Moramo što pre, odmah, pretećem zlu da se suprotstavimo. Ne smemo dozvoliti da nas, i treći put u ovom veku, preteknu događaji “. 38

Sastanak je održan 17. septembra u Udruženju književnika Srbije, ali se malo ko odazvao Draškovićevom pozivu. On je tada rekao da Srbi nemaju na koga da se oslone, da je „Titoistička Jugoslavija“" pred raspadom, da je sve što je pola veka ,raslo na antisrpskoj strategiji“ ujedinjeno protiv Srba i Srbije. ${ }^{39}$

Vuk Drašković je kod režima poneo oreol „izdajnika“ pa je, na primer, jedva izbegao linč od stane pristalica SPS-a prilikom mitinga u Kosovu Polju 29. septembra 1990. godine. Draškovića je sačekao kontramiting, nije mu dozvoljeno ni da govori, a on je osuđen kao čovek koji je u službi „,antisrpske koalicije“

\footnotetext{
${ }^{36} \mathrm{~S}$. Đukić, Između slave $i$ anateme, 159.

${ }^{37}$ Navedeno prema: S. Antonić, Zarobljena zemlja, 109.

${ }^{38}$ Srpska reč, 15. septembar 1990, 37.

39 Srpska reč, 1. oktobar 1990, 8.
} 
i kao političar koji nastupa sa „crnim arsenalom poruka, logora, fizičkih likvidacija i sejanja mržnje“. ${ }^{40}$

Ali, približavanjem izbora i, posebno, posle njih, Vuk Drašković je promenio svoj narativ. Tako je 5. novembra 1990. na saboru SPO rekao da stranka ne želi da ruši Jugoslaviju već da želi novu, sasvim drugačiju Jugoslaviju: ,,Za federaciju smo, čak i po cenu pristajanja na sadašnje unutrašnje granice koje su inače neistorijske i kriminalno postavljene, pod uslovom da savezna država bude višestranačka i demokratska republika ili monarhija, sa jakom centralnom vlašću i pod uslovom da se autonomne pokrajine ili oblasti uspostave svuda gde njihovo postojanje nameću isti razlozi kao i današnjoj Srbiji. Praktično, to znači da bi trebalo zagarantovati teritorijalnu autonomiju Srbima u Hrvatskoj, zatim autonomiju Istre i Dubrovnika, a BiH razdeliti na četiri autonomne oblasti: jednu u kojoj preovlađuju rimokatolici, drugu u kojoj su većina muslimani i dve u kojima pretežu pravoslavni. Držeći se istog principa, preurediti iznutra i Makedoniju, tako da budu nacionalno i kulturno zadovoljeni i tamošnji Makedonci, i Srbi, i Šiptari. Pokrajine i oblasti unutar sadašnjih republičkih granica u Jugoslaviji zamišljamo, približno, kao kantone u Švajcarskoj “ . ${ }^{41}$

Slobodan Milošević je od nekadašnjih pripadnika opozicione inteligencije najveću podršku dobio od Dobrice Ćosića. On je u početku, posle Osme sednice, više puta pohvalno govorio o Miloševićevoj „upornoj borbi za prava srpskog naroda“, ali je i kritički rasuđivao o njegovim autokratskim osobinama. O Miloševiću je Ćosić javno prvi put govorio 24. februara 1989. na slovenačkoj tribini u dvorcu Zemono, gde je bio gost Cirila Zlobeca. Uz pohvale, Ćosić je izrazio i strahovanja za ishod društvenih reformi u Srbiji, a podršku Miloševiću uslovio je demokratskim sadržajem političkih reformi. U Hrvatskoj je ta izjava protumačena kao sumnja u Miloševićevu politiku, a paradoks istorije ogleda se u reagovanju Izvršnog odbora SANU od 30. marta 1989. koji se ogradio od Ćosićeve izjave i izrazio punu podršku srpskom rukovodstvu. ${ }^{42}$

Kada se srpska inteligencija okrenula protiv Slobodana Miloševića, bilo je reči o tome da se Ćosić kandiduje za predsednika Srbije na prvim višestranačkim izborima, jer se smatralo da on jedini ima dovoljno autoriteta da ponudi političku alternativu koja bi porazila autoritarnog Miloševića. Još u leto 1989. kada su Kosta Čavoški, Vojislav Koštunica i Leon Kojen razmišljali o formiranju Demokratske stranke, prvo su razgovarali sa Ćosićem. Odbio ih je, kao i kasnije Antu Markovića, sa kojim nije želeo čak ni da razgovara. ${ }^{43}$

Ali, daleko od toga da je Ćosić bio nezavisan. Za njega više nije bilo dileme. U intervjuu italijanskom listu Il tempo, datom 27. jula 1989, založio se za demokratsko preuređenje Jugoslavije. U konzervativne snage svrstao je JNA, SKJ i veterane jugoslovenske revolucije, a u progresivne - Miloševića: „Ja sam

\footnotetext{
${ }^{40}$ Politika, 30. septembar 1990, 7.

41 Srpska reč, 15. novembar 1990, 19.

${ }^{42}$ Navedeno prema: S. Đukić, Lovljenje vetra, 159.

${ }^{43} \mathrm{~S}$. Đukić, Između slave $i$ anateme, 163.
} 
među onima u opoziciji koji ga podržavaju, ali sa jednom rezervom. Dok se bori za demokratsku federaciju bez ikakve namere za hegemonijom Srbije. Mlad je, hrabar, odlučan i inteligentan. Poseduje veliku sposobnost komuniciranja sa masama. Nesumnjivo, to je najpopularnija ličnost koju je srpski narod imao u 20. veku. Ne strahuje od opozicije i pružio joj je mogućnost da nadvlada titoizam. Otkada je napustio Partiju da bi prešao u vladu, podstakao je jedan novi politički govor: dao je veći prostor sudaru ideja. Đilas može sada da kaže šta želi. I na televiziji. Ponavljam da ne priželjkuje da postane novi Tito". ${ }^{4}$

Ćosić se zatim u drugoj polovini marta 1990. susreo sa Miloševićem. Neposredno posle sastanka u svom dnevniku je zapisao: „, To je prvi srpski komunista koji ima modernu koncepciju ekonomije, komunikacije i razvoja. Nastojao sam da ga ubedim u neminovnost neodložnih demokratskih reformi i da je njegov najvažniji politički zadatak da pomogne i omogući nastajanje ozbiljne i kompetentne opozicije. Zbunio ga je ovaj zadatak. Očigledno je autokratska ličnost. Moje demokratske i reformističke ideje nije prihvatio sa oduševljenjem, ali je radoznalo i sa uživanjem slušao ". ${ }^{45}$ Nešto drugačiju interpretaciju ovog sastanka dao je Borisav Jović. Prema njegovim navodima, Milošević je bio zadovoljan razgovorom, ali se nije složio sa Ćosićevom ocenom da je Jugoslavija preživela i da se ne treba boriti za njen opstanak. Ćosić je ,svim srcem podržao našu politi$\mathrm{ku}$, pre svega bitku za ustavne promene u Srbiji“‘. 46

Mnogim javnim i kulturnim delatnicima u Srbiji izgledalo je da su stavovi Dobrice Ćosića o nacionalnom pitanju nekako prećutno postali usvojen i odobren ideološki temelj službene srpske politike. Za te ljude Ćosić je prošao dug put od državnog pisca i partijskog ideologa do disidenta i natrag. Presudnu ulogu u novom političkom organizovanju Srba u Hrvatskoj, ali i u Bosni i Hercegovini imao je upravo Dobrica Ćosić. Slavoljub Đukić o tome piše: ,, U predvečerje raspada Jugoslavije, među Srbima u Hrvatskoj i Bosni dve ličnosti su nezaobilazne - Milošević i Ćosić. Dobrica je prihvaćen kao čovek koji poznaje 'dušu Srba' i kao nacionalni autoritet, a Slobodan kao harizmatični vođa koji ima državničku moć: oružje, novac, liderski položaj. Obojicu su slavili prekodrinski Srbi, ali je na počecima stvaranja pokreta važniju ulogu imao Ćosić nego Milošević " "47

Ćosić je pomogao da se u ovim republikama organizuju srpske demokratske stranke, a lično je izabrao i njihove lidere - Jovana Raškovića za Hrvatsku i Radovana Karadžića za Bosnu i Hercegovinu. Povezao ih je sa Miloševićem, a čak je Borisavu Joviću rekao da garantuje da su rukovodstva ovih partija „pouzdana“ i obećao je da će pomoći u koordinaciji njihovih politika sa politikom srpskog režima. ${ }^{48}$ Cosić ni kasnije nije sumnjao u ispravnost svoje orijenta-

\footnotetext{
${ }^{44}$ Navedeno prema: Borba, 7. septembar 1989, 7.

${ }^{45}$ Navedeno prema: S. Đukić, Lovljenje vetra, 161.

${ }^{46}$ Borisav Jović, Poslednji dani SFRJ. Dnevničke beleške, Beograd 1995, 125, 130.

${ }^{47} \mathrm{~S}$. Đukić, Lovljenje vetra, 167.

${ }^{48}$ J. Dragović Soso, ,, Spasioci nacije“, 343.
} 
cije. Na pitanje S. Đukića da li je rat bio neminovan, odgovorio je: , Sukob ili pristajanje na potčinjenost, diskriminaciju i tihe izgone. To je bila tadašnja realnost “. ${ }^{49}$ Osim toga, bio je uveren da je Radovan Karadžić sa svojom ,inteligencijom, odlučnošću i borbenošću“ prava ličnost da vodi bosanske Srbe. ${ }^{50}$

Najveći udarac srpskoj opoziciji Ćosić je zadao 1. jula 1990. kada je javno stao uz Miloševića i podržao odluku da se prvo donese novi ustav (u staroj, delegatskoj jednopartijskoj skupštini), pa tek onda raspišu izbori. Objašnjenje koje je dao Politici i Politici Ekspres na sam dan održavanja referenduma bilo je još veće iznenađenje: nijedan prethodni ustav u Jugoslaviji nije bio donesen na potpuno demokratskim načelima, pa je to moglo da važi i za novi srpski ustav; predlog ustava garantovao je uspostavljanje ,jednog neideološkog, otvorenog i slobodnog društva“; otvoreno je izrazio sumnju i u „legitimnost“" lidera opozicije (,u ime kolikog broja građana oni govore?“); višestranačka skupština koja će se izabrati posle donošenja novog ustava „,biće demokratskija od sadašnje slovenačke i hrvatske skupštine, obe izabrane po kardeljevskom samoupravnom modelu“" 51

Ćosić se, osim nad obnovom Jugoslavije, zgražavao i nad obnovom ,četništva“ u Srbiji, pa je otvoreno prezirao Vuka Draškovića i njegovu stranku. U „ekskluzivnom“ intervjuu za NIN nekoliko dana posle referenduma, Ćosić je još jednom naglasio da prema ,četništvu“ kao nacionalnoj ideologiji, moralu i mentalitetu jednog dela srpskog naroda „i nesreći našeg tla i balkanske istorije“ ima isti odnos kakav je imao kada je pisao Deobe i da ga taj roman u aktuelnoj situaciji čini „spokojnijim“ nego što bi bio da ga nije napisao. U skladu sa samoproklamovanom pozicijom nezavisnog intelektualca, poručio je kako ne pripada nijednoj stranci, jer pisac knjiga sa sadržajima i idejama koje je on napisao ne može da stane u jednu političku stranku: „Moje ideje, moje razumevanje $i$ nerazumevanje ljudi i naroda ove zemlje, moji pogledi na ljudsku i srpsku sudbinu, moji pogledi na budućnost Srbije, Jugoslavije, Evrope, ako smem i tu famoznu Evropu da spomenem, ne staju u program nijedne političke stranke ". 52

Ćosić se sa Jovićem susreo 11. septembra 1990. Izjavio je kako nema više „nijednog ozbiljnog razloga“ za postojanje Jugoslavije; za vlast u Srbiji nije želeo da se bori već je želeo da se bori za stvaranje srpske države koja bi trebalo, u raspodeli teritorija sa Hrvatskom, da obuhvati toliko Hrvata u Srbiji koliko bi Srba ostalo u Hrvatskoj. Rekao je i da je ostvario „blisku saradnju“ sa srpskim

${ }^{49}$ S. Đukić, Lovljenje vetra, 168.

${ }^{50}$ Isto, 172.

${ }^{51}$ Dobrica Ćosić: Kraći i bolji put od referenduma ne vidim, Politika, 1. jul 1990, 7. Ćosić je kasnije zažalio zbog ovog svog poteza: „, I prevario sam se i prevarili su me. Imao sam tada informaciju da Slovenci i Albanci pripremaju deklaraciju o otcepljenju, što je bilo tačno, $i$ smatrao sam da se mora požuriti sa donošenjem novog Ustava koji bi Srbiju doveo u bolji položaj. A kada sam rekao: prvo Ustav, to je podrazumevalo i učešće opozicionih stranaka u njegovom stvaranju. Takav je bio dogovor i sa Miloševićem koji nije održao svoje obećanje“. (Navedeno prema: S. Đukić, Lovljenje vetra, 163).

${ }^{52}$ Mač nikada nije bio u koricama, NIN, 6. jul 1990, 34, 38. 
strankama u Hrvatskoj, Bosni i Crnoj Gori i da je lično uticao na Jovana Raškovića da osnuje Srpsku demokratsku stranku; smatrao je da bi bilo dobro da se ona ujedini sa SPS-om. Puno poverenje imao je u Radovana Karadžića i rukovodstvo bosanskih Srba (,vrlo je inteligentno i vrlo pouzdano“) a Joviću je saopštio i da je u toku izrada etničke karte srpskog prostora, „da se jasno prikaže teritorija gde su Srbi i većini - od Šibenika, preko Like, Bosanske krajine, pored Save do Bijeljine svuda su Srbi u većini. U centru Bosne su muslimani. Srbi presecaju i Sandžak, pa se muslimani ne mogu ujediniti. To je budući prostor Srbije“" ${ }^{53}$

U ovom periodu Ćosić se više nego pohvalno izrazio i o predlogu novog srpskog ustava. Čak je izjavio i da je on mnogo bolji od nacrta ustava koje je ponudilo Udruženje književnika Srbije još 27. marta 1988. ${ }^{54}$ Ćosić je Slavoljubu Đukiću dan uoči izbora (8. decembra) rekao: „, Ovo je mirnodopska bitka između četnika i partizana. ${ }^{55}$ [..] U ovakvoj konkurenciji, ja glasam za Miloševića ". 56

Kada je 1991. počeo oružani rasplet jugoslovenske krize, većinski deo srpske intleigencije podržao je Miloševića. Milorad Ekmečić, istaknuti srpski istoričar, Miloševića je oceno kao balkanskog De Gola i smatrao je da srpski narod ima puno istorijsko pravo da izvrši svoje nacionalno ujedinjenje. Raspad Jugoslavije, odnosno ulogu velikih sila u tome, vrednovao je kriterijumima 19. veka; najveću opasnost po srpsko jedinstvo video je u akciji Rimokatoličke crkve i govorio je o ,snažnoj mržnji Austrijanaca“ prema Srbima i ideji jugoslovenskog jedinstva uopšte. Čak je izjavio i da katolička ideja „Evrope regija“ dovodi u pitanje integritet Francuske, Italije i Španije. ${ }^{57}$

I Dobrica Ćosić je otvoreno podržao politiku Slobodana Miloševića, i to preko najvažnijeg režimskog štampanog medija - Politike, koja je intervju sa njim objavila u dva nastavka. U razgovoru sa Miloradom Vučelićem, odmah je rekao kako da on nije neutralan, jer ,neutralnost danas kada se protiv srpskog naroda vodi rat smatram lažju i moralnim kukavičlukom“. ${ }^{58}$ Ocenio je da je Jugoslavija definitivno mrtva i da su je uništile one sile koje su je ,rasturale“ i 1941. kao i ,nacionalističke i secesionističke oligarhije“ Slovenije i Hrvatske: „I to je za mene svršen čin. Ostaju samo da se imenuju pravedne nacionalne granice “. 59

Ćosić je direktno optužio pojedine srpske opozicione stranke da rade na ostvarivanju hrvatskih nacionalnih interesa, ali je on bio „duboko uveren“ da srpski narod više ne želi da živi u zajednici sa narodima „koji ga toliko mrze“. Odbacio je sve kritike da je aktuelan režim u Srbiji „,boljševički““ i optužio je vodeće opozicione snage (,revanšistička opozicija“) da su politički pluralizam obnovile na ,ideološkim pretpostavkama građanskog rata“. Najviše lepih reči Ćosić je

\footnotetext{
${ }^{53}$ Navedeno prema: B. Jović, Poslednji dani SFRJ, 193-194.

${ }^{54}$ NIN, 14. septembar 1990, 27.

${ }^{55} \mathrm{~S}$. Đukić, Između slave $i$ anateme, 165.

${ }^{56} \mathrm{~S}$. Đukić, Lovljenje vetra, 164.

57 Politika, 19. jul 1991, 1.

${ }^{58}$ Politika, 26. jul 1991, 1.

${ }^{59}$ Isto, 2.
} 
imao za Slobodana Miloševića: „,Kao što znate, ja se prema politici Slobodana Miloševića ne odnosim stranački. Nastojim da ga vidim kao hroničar i pisac ovog doba. S tog stanovišta, smatram da posle Nikole Pašića, u Prvom svetskom ratu, nijedan političar nije imao teže uslove i veće breme od Slobodana Miloševića. On se hrabro posvetio obnovi srpske države i spasavanju srpskog naroda od novog porobljavanja i uništavanja, a tom se cilju suprotstavljaju mnogi i moćniji neprijatelji i teško premostive prepreke. ${ }^{60}$

Matija Bećković je podržao Ćosićeve stavove, a Politika je na naslovnoj strani objavila sledeće Bećkovićeve reči: „, Ono što su Srbi dali Jugoslaviji, dali su pod uslovom da se ne iznosi“ “61 On je govorio kako su se Srbi „uspravili pod udarcima, otreznili uvredama, probudili nepravdama“, kao i da nezavisna hrvatska država ne može da postoji sa Srbima. Smatrao je i da je treći svetski rat izvestan: „, Usuđujem se da kažem: ako u Jugoslaviji intervenišu strane trupe, imaće posla do Kamčatke ". ${ }^{62}$ Bećković je smatrao da srpski narod ima pravo na svoje nacionalno ujedinjenje: „Koliko znam, velika Srbija je jedna od neprijateljskih floskula smišljenih u austrougarskim ratnim štabovima. Velikom se naziva država koja je onolika koliki je njen narod. To je jedinstven slučaj na svetu. Tako imamo malu Nemačku i veliku Srbiju. Ili bolje rečeno, Srbija je velika kad se ujedini a Nemačka nije. I zato je najveća opasnost po mir nepostojeća velika Srbija a ne postojeća Nemačka“63

Bećković nije imao previše lepih reči ni za srpsku opoziciju: „Iz uverenja da je vlast slaba nastala je pogubna predrasuda da je može smeniti ko bilo. Svejedno ko je i šta joj je alternativa. Ta zabluda traje do njenog uspostavljanja. Prave alternative $i$ nema. Više se razlikuju ljudi nego programi. Niko ih nije birao, izabrali su se sami i uspostavili hijerarhiju kao nekadašnji generalni sekretari “64

Istoričar Vasilije Krestić je ocenio da je došlo vreme „prelomnih i sudbinskih rešenja“, jer je srušena vekovna jugoslovenska iluzija kod srpskog naroda. Zato su Srbi morali da stvore svoju nacionalnu državu, a pri formiranju novih granica morale su se uzeti u obzir i negativne posledice genocida nad srpskim narodom. ${ }^{65}$ Akademik Pavle Ivić, jedan od najistaknutijih srpskih lingvista, smatrao je da je srpski nacionalni interes da stvori stabilnu demokratsku državu koja će okupiti sve oblasti ,gde su Srbi u većini i one narode koji žele zajedništvo sa nama“. Optužbe protiv Slobodana Miloševića su neutemeljene, jer je on oslobodio Srbiju ,vazalnog odnosa“ prema sopstvenim pokrajinama, ,a to se nije moglo postići bez buđenja uspavane nacionalne svesti““. ${ }^{66}$ I književnik Boško Petrović,

\footnotetext{
${ }^{60}$ Politika, 27. jul 1991, 8.

${ }^{61}$ Politika, 2. avgust 1991, 1.

62 Isto.

${ }^{63}$ Politika, 3. avgust 1991, 1.

${ }^{64}$ Isto, 8.

${ }^{65}$ Politika, 9. avgust 1991, 1.

${ }^{66}$ Politika, 23. avgust 1991, 7.
} 
predsednik Matice srpske podržao je Miloševićevu politiku: „Nacionalno-državnu strategiju u aktuelnoj politici Srbije mogla je pokrenuti samo ličnost od izrazito političkog dara, samopregora, hrabrosti i energije, a pošto je to učinio Slobodan Milošević, jasno je da on takva ličnost jeste ". ${ }^{67}$

Slične stavove iznosio je i književnik Milorad Pavić, koji je tada bio na vrhuncu popularnosti, što je dovelo i do njegovog članstva u SANU. Pavić je potpuno preuzeo osnovni Ćosićev politički narativ - Srbi su poznati po tome što su uvek u ratu imali dobre stratege, ali ih u miru nisu imali veoma dugo: ,, Sada, čini mi se, i Milošević i Rašković imaju takve strategije. I to je važno za Srbiju". ${ }^{8}$ Milorad Pavić nije bio u dilemi - unutrašnje granice u Jugoslaviji morale su da se promene, a Srbija iz Jugoslavije nije smela da izađe u gorem položaju nego što je u nju ušla. O Miloševiću je rekao sledeće: „, Gospodin Milošević je prvi i poslednji političar koji je usred antisrpski nastrojene komunističke Jugoslavije učinio nešto dobro i veliko za Srbiju. Svi znamo pod kako teškim uslovima, koliko i kako u veoma teškom vremenu. Ali ja ne vidim njega samog. Kao vladu srpskog naroda vidim i Raškovića, i Babića, i Karadžića, i Hadžića, i Jovića, i Draškovića, i Šešelja, i Mićunovića, kao i Koštunicu i Paroškog “. ${ }^{69}$

Srpska inteligencija se protiv Slobodana Miloševića prvi put pobunila novembra 1991, u jeku ratnog vihora u Hrvatskoj. Tada je 18 članova SANU uputio apel protiv rata, za mirno rešavanje sukoba u Jugoslaviji: „Ne verujemo $u$ svrsishodnost ovog rata. Ne verujemo u one koji ga vode. Ne verujemo u one koji ga, svesno ili nesvesno, potpiruju. Ne verujemo u pobede koje vode u nove rato$v e "{ }^{70}$ Apel su potpisali R. Anđus, I. Antić, M. Garašanin, M. Gašić, M. Pavlović, P. Palavestra, M. Pantić, B. Pekić, B. Popović, S. Rajčić, B. Reljić, S. Selenić, M. Simić, Lj. Simović, M. Srbinović, D. Srejović, D. Stefanović i N. Tasić. Akademija se istoga meseca, na redovnoj sednici, ogradila od ovog antiratnog apela. Dejan Medaković, generalni sekretar SANU, naglasio je da „apel ne predstavlja stav institucije, već samo potpisnika“. ${ }^{71}$

Približavanje srpske inteligencije režimu Slobodana Miloševića predstavlja istorijski fenomen koji nije lako objasniti, ali je jasno da je ostavio sudbonosne posledice po ukupnu istoriju srpskog naroda na kraju 20. veka. Srpska inteligencija nije pružila značajniji otpor uvođenju komunističkog poretka, a strah od represije $\mathrm{u}$ tome nije bio presudan faktor. Za razliku od ostalih istočnoevropskih socijalističkih zemalja, Jugoslavija je marksizam shvatala daleko ozbiljnije, pa nije ni imala prave disidente koji bi napravili iskorak ka individualnom društvu,

${ }^{67}$ Politika, 6. septembar 1991, 7.

${ }^{68}$ Ana Šomlo, Hazari ili obnova vizantijskog romana. Razgovori sa Miloradom Pavićem, Beograd 1990, 106-108, 111.

${ }^{69}$ Politika, 13. septembar 1991, 7.

${ }^{70}$ Navedeno prema: www.vreme. com/arhiva_html/457/8.html

${ }^{71}$ Isto. 
ka društvu građanske demokratije. Zbog toga je i većina marksističkih intelektualaca $\mathrm{u}$ vreme raspada zemlje prihvatila nacionalizam kao novu ideologiju. ${ }^{72}$

Komunizam i nacionalizam imaju dosta zajedničkih osobina na teorijskom nivou, a najvažnija jeste upravo antiindividualizam. U oba slučaja u pitanju je kolektivistička praksa, zasnovana na istom tipu matrice - postojanje privilegovane posebne grupe unutar društvene zajednice (,radnička klasa“, odnosno „,nacija“). Nasuprot istorijskom i pravnom subjektivitetu građanina-pojedinca, na čemu se zasnivaju moderne liberalne demokratije, i komunizam i nacionalizam kreiraju i na političkom nivou priznaju samo identitet kolektiva, a njegove ideološke vrednosti temeljnim vrednostima zajednice. U tom smislu je i komunistički mit o „svetloj budućnosti“ i socijalizmu kao jedinom izboru bio blizak nacionalističkom mitu o prošlosti kao prirodnom stanju. U oba slučaja, neophodno je bilo homogenizovanje društva svim sredstvima $i$ apsolutna vlast. ${ }^{73}$

Jugoslavija je imala veoma malo liberalnih intelektualaca koji bi se zalagali za širenje ideja pluralizma, pravne države, višestranačkih izbora, slobodnog tržišta, individualnih sloboda i ljudskih prava. Većina intelektualaca nije bila u sukobu sa vlastima, pa je krajem 80 -ih godina 20. veka veoma lako prihvatila nacionalizam, jer su, kako ističe S. Malešević, bili „organski zakonodavci“, odnosno oni su smatrali da su njihova učenja i ideje potpuno naučno zasnovani i istiniti.

Za državnu inteligenciju marksizam-lenjinizam je bio čista nauka koja je otkrila „najviše zakone istorije“, za intelektualce koji su režim „kritikovali“ sa levog krila, važili su slični principi - slediti program ranih radova „klasika marksizma“; njihova kritika državne strategije bila je samo radikalnija i ,čistija“ interpretacija Marksovih ideja. Na kraju su se oni stopili sa nacionalistima koji su takođe imali ,zakonodavni“" pogled na svet, samo što je njihov cilj bio osnivanje nezavisne nacionalne države na etničkim principima. Ali, i njihove vizije etnički strukturirane nacije bile su utemeljene na strogo determinističkom i naturalističkom principu kad se postojanje i razvoj nacija doživljava u terminima prirodnih zakonitosti. $^{74}$

„Partijnost“ itelektualizma zamenjena je nacionalnim diskursom, a nekadašnji dijalektički materijalizam ,etničkim materijalizmom“. Dominantna osobina takvog tipa intelektualca jeste shvatanje da je intelektualni život borba, a duhovna ostvarenja samo deo ,borbene akcije“. Razumevanje drugačijeg mišljenja ili pogleda na svet bilo je samo u funkciji pripreme ,pobedonosne borbe“ protiv „,suparnika“; svest o potrebi uvažavanja i eventualnog prihvatanja suprotnog mišljenja jednostavno nije postojala. Taj proces najnegativnije posledice ostavio je u filozofiji koja nije do-

${ }^{72} \mathrm{O}$ društvenoj ulozi i tipovima intelektualaca videti opširnije u: Siniša Malešević, $O d$ organskih zakonodavaca do organicističkih tumača: intelektualci u Jugoslaviji i postjugoslovenskim državama, Reč, Časopis za književnost, kulturu i društvena pitanja, 70/16, jun 2003, 33-50.

${ }^{73}$ Nenad Dimitrijević, Reči i smrt: nacionalistička konstrukcija stvarnosti, Reč, 60/5, decembar 2000, 139-140.

${ }^{74} \mathrm{~S}$. Malešević, Od organskih zakonodavaca do organicističkih tumača, 43-44. 
zvoljavala ni teorijsku kritiku ideologije, jer je to automatski značilo i kritiku poretka, a socijalistička ideologija (i poredak) bila je zasnovana na „nauci“ koja je samo trebalo da legitimiše postojeću stvarnost i morala je da bude u njenoj službi.

Intelektualci koji su podržali srpski režim dobili su priliku da učestvuju u „stvaranju istorije“, a Slobodan Milošević mogućnost da prelegitimiše svoj autoritarni poredak. Savez između njih bio je neminovan, a odluka dela inteligencije da podrži takav režim bila je sudbonosna u vremenu raspada Jugoslavije i dovela je srpski narod do najvećeg poniženja u njegovoj modernoj istoriji.

Kosta Nikolić

\section{THE HUMANISTIC INTELLIGENCE AND RESTORATION OF THE PARLAMENTARISM IN SERBIA}

\section{Summary}

Multiparty system in Serbia was result of the populist revolution conducted by the Slobodan Milošević in Serbia's political life in late 1980-ties. The Serbian opposition had no clear alternative to Milošević's national program: political life was dominated by the kind of the political and national forces that it could not control or influence. All of the major Serbian political opposition parties in their programs and even activities, just followed the political and national mainstream, that became dominant in the Serbian public after 1988. It acted mainly on daily activities or trying to challenge or deny public standpoints which Milošević placed as a political standard of the moment: unified Serbia and federative Yugoslavia. This was the main reason why real democratic alternatives in Serbia were not created. And it leaded to the situation where Serbian opposition was without a great effort in winning the parliamentary elections. The first multiparty parliamentary elections held in communist Serbia in 1990, were marked by a series of events characteristic to the epoch of transition from one-party to multi-party system: regime repression of pro-opposition media, and a high degree of political intolerance between opponents. The political system in Serbia during the last decade of the $20^{\text {th }}$ century could be marked as the type of authoritarian regime in which there were democratic and parliamentary institutions, but not substantive democracy. Parliamentary system and other institutions, regardless to their democratic form, were just facades for personal power by Slobodan Milošević. 